\title{
TERC Gene Mutation
}

National Cancer Institute

\section{Source}

National Cancer Institute. TERC Gene Mutation. NCI Thesaurus. Code C152080.

A change in the nucleotide sequence of the TERC gene. 